УДК 811.111 '37’42

DOI https://doi.org/10.26661/2414-1135-2021-84-6

\title{
ФУНКЦІї ЛЕКСИЧНИХ ОДИНИЦЬ У СЕМАНТИЧНОМУ ПРОСТОРІ ХУДОЖНЬОГО ТЕКСТУ (НА МАТЕРІАЛІ РОМАНІВ ДЖОНА МАКСВЕЛЛА КУТЗЕЕ)
}

\author{
Головащенко Ю. С. \\ кандидат філологічних наук, \\ асистент кафедри комунікативної лінгвістики та перекладу \\ Чернівецький національний університет імені Юрія Федьковича \\ вул. Садова, 5, Чернівиі, Украӥна \\ orcid.org/0000-0003-0224-5565 \\ yuliagolovashchenko@yahoo.com
}

Ключові слова: художній текст, семантичний простір, лексична одиниия, функиія, авторський стиль, контекст.
Стаття присвячена питанню функцій лексичних одиниць у художньому тексті. Художній текст приваблює неповторним поєднанням змісту і смислу, що приховується під поверхнею мовного вираження та підлягає інтерпретації. Найбільш ефективним та інтрепретативно значущим видається лексичний рівень, тобто рівень слів, значення яких, занурене в мовну канву твору, набуває нової семантичної цінності з огляду на зміст художнього тексту. У статті лексичні одиниці розглядаються як конституенти лексичної структури, яка становить основу формування семантичного простору художнього тексту, тобто простору його значення. Побудова лексичної структури семантичного простору художнього тексту уможливлюється шляхом відбору таких лексичних одиниць, що відповідають жанровій специфіці художнього тексту. Витлумачення жанру відносно художнього тексту стосується аспекту тематичного спрямування, тобто превалюючих тем, що висвітлені в художньому творі та $є$ характерними для конкретного жанру. Не менш важливим складником жанру $є$ стиль, який трактується як стильова домінанта авторської творчості і передбачає арсенал технік творення тексту. У такому світлі авторський стиль проєктується на художній текст у функційному річищі - в особливостях функціювання лексичних одиниць задля забезпечення цілісності і зв' язності художнього тексту та реалізації його змістово-смислової єдності. У реферованій статті функції лексичних одиниць розглядаються як маркери індивідуального авторського стилю, що репрезентують властиві автору особливості вживання релевантних лексичних одиниць у ході текстотворення. 3'ясування функцій лексичних одиниць має два етапи: контекстуалізацію - виявлення слів у межах мікроконтексту та співвіднесення 3 макроконтекстуальною ситуацією твору, та інтерпретацію - співвіднесення ролі лексичних одиниць у загальній перспективі розгортання художнього тексту, тобто ймовірне розшифрування елементів авторського задуму. Серед найбільш уживаних функцій у семантичному просторі романів Джона Максвелла Кутзее $є$ зображувально-описова, сюжетно-композиційна та емотивна. 


\title{
FUNCTIONS OF LEXICAL UNITS IN SEMANTIC SPACE OF LITERARY TEXT (BASED ON NOVELS BY JOHN MAXWELL COETZEE)
}

\author{
Holovashchenko Yu. S. \\ Candidate of Philological Sciences, \\ Assistant Professor at the Department of Communicative Linguistics \\ and Translation \\ Yuriy Fedkovych Chernivtsi National University \\ Sadova str., 5, Chernivtsi, Ukraine \\ orchid.org/0000-0003-0224-5565 \\ yuliagolovashchenko@yahoo.com
}

Key words: literary text, semantic space, lexical unit, function, author's style, context.

\begin{abstract}
The article is dedicated to the issue of functions of lexical units in a literary text. A literary text appeals with unique combination of content and sense, which is hidden beneath the linguistic surface and is subjected to interpretation. The most effective and interpretatively significant is the lexical level, i.e. the level of words whose meanings, while submerged in the linguistic environment of the text, acquire some new semantic value in relation to the content of the literary text. In this article lexical units are regarded as constituents of lexical structure that lays a foundation of formation of the semantic space of a literary text, i.e. the space of its meaning. Construction of the lexical structure of semantic space of a literary text is possible through selection of lexical units that correlate with generic peculiarities of the text. The definition of genre in relation to a literary text concerns the prevailing themes that are highlighted in the text and are specific for every single genre. Style is another important constituent of genre. It is defined as dominant style tendencies of author's literary work, primarily pertaining to a range of techniques of text production. In this vein, author's style is projected onto a literary text in the functional aspect, i.e. featuring peculiarities of functions of lexical units that guarantee cohesion and coherence of a literary text and realization of its unity of content and sense. In the present article functions of lexical units are seen as markers of individual author's style, representing inherent for the author patterns of use of relevant lexical units in the course of text production. Determining these functions incorporates two stages, i.e. contextualization - locating words within microcontext and correlating them with macrotextual situation - and interpretation - correlating the functions of lexical units with the general perspective of text production, i.e. probable translation of elements of the author's intention. Among the most commonly used functions in the semantic space of novels by John Maxwell Coetzee are descriptive, plot-designing and emotive.
\end{abstract}

Постановка проблеми. У мовознавчій науці сьогодення плюралізм тлумачень художнього тексту (далі - ХТ) відображає довгий шлях розвитку і становлення різноманітних лінгвістичних течій. Серед них - структуралістське бачення тексту як послідовності мовних знаків, які кодують певний зміст [4]; інтерпретація ХТ у руслі відтворення авторської картини світу, що передбачає звернення до концептуального аналізу [11]; протиставлення тексту і дискурсу та тлумачення першого як продукту динамічного дискурсотворення $[17 ; 20]$. Попри багатоманіття підходів, які визначають відповідні алгоритми й інструментарій дослідження
XТ, видається беззаперечною думка, що ХТ привертає увагу передусім завдяки глибинному смислові, який розкривається поступово в ході художнього переосмислення значень слів [19].

Поняття семантичного простору ХТ якраз уможливлює акцент суті ХТ на його смисловому континуумі, що відбивається в системно упорядкованій лексичній структурі та реалізується на рівні текстового змісту [5, с. 5]. Семантичний простір реалізується в словесній канві твору: значення лексичних одиниць, занурених у контекст, торує шлях для композиційно-сюжетного розгортання i, відповідно, вираження змісту ХТ. На думку 
М.М. Бахтіна, «усі слова пахнуть (...) певним твором, певною людиною, поколінням, віком, днем і часом. Кожне слово пахне контекстом і контекстами, в яких воно жило своїм соціально напруженим життям; усі слова і форми сповнені інтенціями» $[1$, с. 46]. Оскільки лексичний рівень $\epsilon$ чи не найбільш продуктивним у текстотворенні та інтерпретації XТ, важливо з'ясувати, у чому полягають функції лексичних одиниць, на основі яких виформовується семантичний простір художнього твору.

Аналіз останніх досліджень i публікацій. Питання функції відносно мовних одиниць лежить в основі теорії про репрезентаційну функцію мови (K. Bühler [13]) і напряму функціональної граматики (M.A.K. Halliday, M.I.M. Matthiessen [18]). Дослідження функцій лексичних одиниць уможливило їхню класифікацію за критеріями змісту внутрішні і зовнішні функції, та ступенем власності - власні і невласні (М.М. Морковкін [7]).

Дослідження функцій лексичних одиниць у межах художнього твору є також досить розпрацьованим напрямом: наприклад, у розвідках про функції лексичних одиниць на позначення часопростору (Д.В. Козловська [6]), про функції діалектизмів у ХТ (Л.Г. Самотік [8]), про функції безеквівалетної лексики поетичного твору (О.Ю. Тупиця [12]); про стилістичні функції лексики англомовної новели (А.В. Сухова [10]). Утім, питання семантичного простору ХТ і відтак функцій лексичних одиниць, що викарбовують смислову цілісність ХT, потребує пильнішої уваги та активнішого інтересу з боку наукового кола послідовників лінгвістики тексту.

Мета статті - 3'ясувати функції лексичних одиниць у межах семантичного простору XT. Завдання статті - проаналізувати індивідуально-авторський стиль як складник жанрово-стильової парадигми ХТ; висвітлити особливості функційного аналізу лексичних одиниць у межах XT; контекстуалізувати та інтерпретувати функції тематично значущих лексичних одиниць у межах семантичного простору романів Джона Максвелла Кутзее.

Об'сккт дослідження - лексичні одиниці, що виформовують семантичний простір XT.

Предмет дослідження - функції лексичних одиниць, що виформовують семантичний простір XТ.

Виклад основного матеріалу дослідження. Як зауважувалося вище, лексичний рівень $\epsilon$ найбільш продуктивним у реконструкції семантичного простору ХT. Саме лексична структура становить кістяк семантичного простору ХT, оскільки у смислових зв'язках між значеннями відтворюється семантична вісь ХТ. Лексична структура ХТ виформовується в ієрархічному ключі - від об'ємних лексичних мікросистем (лексико-семантичних полів) до частиномовно обмежених семантичних підкласів і менших лексичних угруповань.

Лексико-семантичну структуру ХТ трактуємо як сукупність лексико-семантичних мікросистем, що детермінується індивідуально-авторською мовною картиною світу i жанрово-стильовою парадигмою ХТ [5, с. 6]. Відтак індивідуально-авторська мовна картина світу є сконденсованим вербалізованим авторським знанням про світоустрій; жанрово-стильова парадигма зумовлює тематичне спрямування XТ як літературно-художнього твору i, відповідно, арсенал мовних одиниць для висвітлення цих тем у ХТ [5, с. 5-6]. Стильовий компонент цієї парадигми концентрується на індивідуально-авторському стилі - здійснення мовними одиницями функцій у контексті XT. I.В. Тарасова вважає, що стильова домінанта авторської творчості інтегрує превалюючі теми, жанрові особливості, техніки і прийоми для звершення автором текстотвірної й естетичної діяльності [11, с. 7]. Відповідно, у ХТ стильові особливості слід розглядати також у функційному річищі; водночас функційний аспект зумовлений автором ХT, який, керуючись власними художньо-естетичними мотивами, обирає релевантне функціональне оформлення жанротвірній лексиці в контексті.

Функційний аналіз у площині ХТ уможливлює спостереження мови «в дії» з урахуванням індивідуально-авторського чинника. Функціювання лексичних одиниць в авторському художньому творі зумовлене специфікою авторського художнього задуму, напрямом розгортання авторської думки, авторськими преференціями щодо «кодування» смислового навантаження, контекстуально-ситуативними факторами тощо.

Функційний аналіз розкривається у межах функціональної парадигми, ключовим елементом якої $є$ «розуміння мови як цілеспрямованої системи засобів вираження» (I.А. Бехта) [2, с. 23]. Оскільки мовні одиниці як складники мовної системи слугують засобами спілкування й обміну інформацією, цілком логічно, що у конкретній комунікативній ситуації вони уможливлюють досягнення певної мети, що й утілюється в арсеналі використаних функцій.

Щодо XТ, який також є свого роду повідомленням, що характеризується художнім змістом, увага концентрується на внутрішньотекстових функціях лексичних одиниць, тобто таких, що забезпечують реалізацію семантичної $i$ змістової єдності та иілісності ХT. Виявлення цих функцій уможливлюється уважним прочитанням й осмисленням XТ, співвіднесенням семантики лексичних одиниць із макроконтекстом художнього твору. Згаданий механізм передбачає залучення 
інтерпретативних стратегій, оскільки інтерпретація тексту має на меті витлумачити, розкрити, пояснити смисл. Отже, інтерпретація ХТ полягає у тому, аби зібрати чи скомбінувати релевантні фрагменти для з'ясування цілісного текстового смислу, об'єктивованого у матеріальній формі ХТ [3].

У зв'язку 3 цим ефективним методом виявлення функційного потенціалу релевантних лексичних одиниць у семантичному просторі ХT $є$ контекстуально-інтерпретативний, що передбачає контекстуалізацію та інтерпретацію (О.О. Селіванова). Спершу лексичні одиниці ідентифікуються у межах мікроконтексту художнього твору й аналізуються у взаємозв'язку макроконтексту та змістово-тематичного аспекту ХТ. Далі роль лексичних одиниць у виокремлених контекстуальних уривках співвідноситься із ймовірним художнім задумом автора, загальною стратегією змістово-смислового розгортання ХТ - одним словом, осмислюється 3 огляду на релеватні контекстуальні чинники [9]. Отже, із контекстуально-інтерпретативним методом стає можливим конкретизувати функцію, імплементовану в XТ, й описати іiі значущість у семантичному просторі художнього твору.

Проілюструємо прикладом із роману Джона Максвелла Кутзее „Foe”: „, The room was lit by a single window, through which poured the afternoon sun. The view was to the north, over thr roofs of Whitechapel. For furniture there was a table and chair, and a bed, slovenly made; one corner of the room was curtained off" "[14, с. 113]. У цьому фрагменті знаходимо лексичні одиниці, що входять до лексико-семантичного мікрополя „Man-made Environment" / "Матеріальне середовище". У ході контекстуалізації з'ясовуємо, що поданий уривок представлений у сюжетній ситуації приходу головної героїні Сари та іїі глухого супроводжуючого П'ятниці до пана Фоу - відлюдькуватого письменника, який погодився написати їі історію перебування на безлюдному острові. Зайшовши до його будинку, Сара одразу звертає увагу на скромність помешкання. Оскільки в уривку бачимо опис кімнати, фіксуємо, що лексичні одиниці з семантикою матеріального світу виконують зображувально-описову функцію, тобто відтворюють умовну картину цієї кімнати.

Поглянемо на другий приклад і наведемо хід аналізу: „If you don't have a certificate, how come you are Maria Regina's teacher?' I said. 'I don't understand.'// The answer, which again took a long time to squeeze out of him, was that, for subjects like music and ballet and foreign languages, schools were permitted to hire persons who had no qualifications, or at least did not have certificates of competence. These unqualified persons would not be paid salaries like proper teachers, they would instead be paid by the school with money collected from parents like me" $[15$, c. 160]. Передусім ідентифікуємо мікроситуацію: одна 3 героїнь, мати Марії-Регіни, незадоволена новим вчителем англійської мови, до якого ії донька відчуває симпатію. Цим учителем, власне, $\epsilon$ досліджуваний письменник - Джон Максвелл Кутзее. Запросивши його додому, вона починає розпитувати про його професійну підготовку i дуже обурюється, коли дізнається, що у нього немає педагогічної освіти. Далі спробуємо інтерпретувати значущість слів із семантикою освіти, зокрема teacher certificate, qualifications, a school, a subject, a teacher, що входять до лексико-семантичного мікрополя „Education” / «Освіта». Із аналізу уривку робимо висновок, що вони відіграють роль у сюжетному розвитку і реалізації композиції як побудови історії твору, тобто виконують сюжетно-композииійну функцію.

Наведемо ще один приклад: „I love you too, God. I love the stones and the sand and the bushes and the sky and Klawer and those others and every worm, every fly in the world. But God, don't let them love me. I don't like accomplices, God, I want to be alone" [16, с. 95-96]. У цьому фрагменті знаходимо лексичні одиниці з семантикою природи, які належать до лексико-семантичного мікрополя „Natural Environment” / «Природне середовище», - наприклад, a stone, sand, a bush, the sky, a worm, a fly. Проаналізувавши їхню функційну сторону, робимо висновок, що вони виконують емотивну функиію, яка полягає у зверненні до природного тла для увиразнення психоемоційного стану чи психологічної атмосфери. Як бачимо 3 уривка, любов постає у глобальному масштабі не лише як любов до Бога, але й до створеного ним світу й оточуючих людей. Використання слів на позначення природних явищ слугує підсиленню почуття любові, висловленого головним героєм Богові як вдячність за пережиті ним складні випробування.

Висновки і перспективи подальших досліджень. Отже, з'ясування важливих функцій релевантних лексичних одиниць дає змогу отримати більш вичерпне усвідомлення авторського художнього стилю, тематики романів та арсеналу засобів реалізації змістово-смислового потенціалу його творів. У цьому світлі функції видаються текстотворчими i авторсько відцентрованими, оскільки вони, зодного боку, слугують розгортанню сюжетно-композиційної паралелі - чергуванню сюжетного просування (сюжетно-композиційна функція), дескриптивних фрагментів (зображувально-описова функція) та художньо-смислових акцентів (емотивна функція). 3 іншого боку, функції лексичних одиниць, значення яких утворюють семантичний простір ХТ, відтворюють авторський стильовий імператив - характерну манеру 
побудови змістово-смислової єдності та їі втілення у мовному полотні твору.

Перспектива дослідження вбачається у дослідженні творчості сучасних південноафриканських письменників, реконструкції семантичних просторів їхніх творів й аналізу функцій тематично релевантних лексичних одиниць.

\section{ЛIТЕРАТУРА}

1. Бахтин М.М. Собрание сочинений в семи томах / ред. С.Г. Бочаров, Н.И. Николаев. Москва : Изд-во «Русские словари»; Языки славянской культуры, 2003. Том 1 : Философская эстетика 1920-х годов. 958 с.

2. Бехта I.A. Дискурс наратора в англомовній прозі. Київ : Грамота, 2004. 304 с.

3. Воронкова Н.Р. Інтерпретація та лінгвістичний аналіз художнього тексту. Наукові записки КДПУ. Серія: Філологічні науки (Мовознавство). 2015. Вип. 138. С. 409-411.

4. Гальперин И.Р. Текст как объект лингвистического исследования / отв. ред. Г.В. Степанов. Изд. 7. Москва : «ЛИБРОКОМ», 2009. 144 с.

5. Головащенко Ю.С. Семантичний простір романів Джона Мексвелла Кутзее : автореф. дис. ... канд. філол. Наук : 10.02.04. Чернівці, 2018. 20 c.

6. Козловська Д.В. Стилетворча роль топопоетонімів у текстах романів Лариси Денисенко. Наукові записки Національного університету «Острозька академія»: серія «Філологія». 2019. № 7(75). С. 56-59.

7. Морковкин В.В. Основные функции лексических единиц. Вестник РУДН. Вопросы образования. Языки и спечиальность. 2007. № 1. С. $43-51$.

8. Самотик Л.Г. Лексика современного русского языка: учеб. пособие. 2-е изд., стер. Москва: Флинта, 2012. 510 с.

9. Селіванова О. Методи дослідження тексту в сучасній лінгвістиці. URL: https://uchika. in.ua/metodi-doslidjennya-tekstu-v-suchasnijlngvistici.html (дата звернення : 29.09.2021).

10. Сухова А.В. Англомовна новела (XIX-XX ст.): лінгвостилістичний та прагматичний аспекти : дис. ... канд. філол. Наук : 10.02.04. Запоріжжя, 2017. 264 c.

11. Тарасова И.А. Поэтический идиостиль в когнитивном аспекте: монография 2-е изд., перераб. Москва : ФЛИНТА, 2012. 196 с.

12. Тупиця О. Безеквівалентна лексика в поетичному тексті: проблема створення етномовної картини світу. Mauritius, Beau Bassin: LAP LAMBERT Academic Publishing RU, 2018. $117 \mathrm{c}$.

13. Bühler K. Theory of Language: The Representational Function of Language / Translated by Donald
Fraser Goodwin. Amsterdam; Philadelphia: John Benjamins Publishing Company, 2011. 518 p.

14. Coetzee J.M. Foe. New York : Penguin Books, 1987. $158 \mathrm{p}$

15. Coetzee J.M. Summertime: Scenes from Provincial Life. London : Harvill Secker, 2009. 266 p.

16. Coetzee J.M. Waiting for Barbarians. New York : Penguin Books, 1999. 152 p.

17. De Beaugrande R. Discourse Analysis and Literary Theory: Closing the Gap. Journal of Advanced Composition. 1993. Vol. 13. No. 2. Pp. 423-448.

18. Halliday M.A.K., Matthiessen M.I.M. An Introduction to Functional Grammar. $3^{\text {rd }}$ edtition. London: Hodder Education Publishers, 2004. 700 p.

19. Wetherhill P.M. The Literary Text: An Examination of Critical Methods. Berkeley; Los Angeles : University of California Press, 1974. 331 p.

20. Widdowson H.G. Text, Context, Pretext: Critical Issues in Discourse Analysis. Oxford : Blackwell Publishing, 2004. 185 p.

\section{REFERENCES}

1. Bakhtin, M.M. (2003). Collected works in seven volumes [Sobraniye sochineniy $\mathrm{v}$ semi tomakh] (S.G. Bocharov, N.I. Nikolaev, eds.) (Vol 1: Philosophical Aesthetics of the 1920s). Russkie Slovari Publishing.

2. Bekhta, I.A. (2004). Discourse of the narrator in English prose [Diskurs naratora $\mathrm{v}$ anhlomovniy prozi]. Hramota.

3. Voronkova, N.R. (2015). Interpretation and linguistic analysis of the literary text [Interpretatsiya ta linhvistychnyy analiz khudozhn'oho tekstu]. Scientific Notes of the KDPU. Series: Philological Sciences (Linguistics), 138, 409-411.

4. Galperin, I.R.(2009). Text as an object oflinguistic research [Tekst kak obyekt lingvisticheskogo issledovaniya] (Stepanov, G.V., Ed.) (7 $7^{\text {th }}$ edition). LIBROKOM Publishing.

5. Holovashchenko, Yu.S. (2018). The semantic space of the novels by John Maxwell Coetzee [Semantichnyy prostir romaniv Dzhona Maksvella Kutzee]. Candidate's Thesis Abstract: 10.02.04.

6. Kozlovska, D.V. (2019). Style-forming role of topopoetones in the texts of novels by Larysa Denysenko [Styletvorcha rol' topopoetonimiv v tekstakh romaniv Larysy Denysenko]. Scientific Notes of the National University "Ostroh Academy»: "Philology» series, 7(75), 56-59.

7. Morkovkin, V.V. (2007). Basic functions of lexical units [Osnovnyye funktsii leksicheskikh yedinits]. RUDN Bulletin. Educational Issues. Languages and Specialties, 1, 43-51.

8. Samotik, L.G. (2012). Vocabulary of the modern Russian language: textbook [Leksika 
sovremennogo russkogo yazyka: ucheb. posobiye]. Flinta Publishing.

9. Selivanova, O. Methods of Text Research in Contemporary Linguistics [Metody doslidzhennia tekstu v suchasniy linhvistytsi]. URL: https://uchika.in.ua/metodi-doslidjennyatekstu-v-suchasnij-lngvistici.html (access date: 29.09.2021).

10. Sukhova, A.V. (2017) English short story (XIX-XX centuries): linguistic and pragmatic aspects [Anhomovna novela (XIX-XX st.): Linhvostylistychnyy i prahmatychnyy aspekty]. Candidate's thesis: 10.02.04.

11. Tarasova, I.A. (2012). Poetic idiostyle in the cognitive aspect [Poeticheskiy idiostil' $\mathrm{v}$ kognitivnoy aspekte] ( $2^{\text {nd }}$ edition). Flinta Publishing.

12. Tupytsia, O. (2018). Non-equivalent vocabulary in the poetic text: the problem of the root of the ethnical world picture [Bezekvivalentna leksyka $\mathrm{v}$ poetychnomu teksti: problema stvorennia etnomovnoi kartyny svitu]. LAP LAMBERT Academic Publishing RU.
13. Bühler, K. (2011). Theory of Language: The Representational Function of Language (Donald Fraser Goodwin, Transl.). John Benjamins Publishing Company.

14. Coetzee, J.M. (1987). Foe. Penguin Books.

15. Coetzee, J.M. (2009). Summertime: Scenes from Provincial Life. Harvill Secker.

16. Coetzee, J.M. (1999). Waiting for Barbarians. Penguin Books.

17. De Beaugrande, R. (1993) Discourse Analysis and Literary Theory: Closing the Gap. Journal of Advanced Composition, Vol. 13, 2, 423-448.

18. Halliday, M.A.K., Matthiessen, M.I.M. (2004). An Introduction to Functional Grammar ( $3^{\text {rd }}$ edtition). Hodder Education Publishers.

19. Wetherhill, P.M. (1974). The Literary Text: An Examination of Critical Methods. University of California Press.

20. Widdowson, H.G. (2004). Text, Context, Pretext: Critical Issues in Discourse Analysis. Blackwell Publishing. 